Marie L. Woolley • Charles A. Marsden •

Andrew J. Sleight · Kevin C. F. Fone

\title{
Reversal of a cholinergic-induced deficit in a rodent model of recognition memory by the selective $5-\mathrm{HT}_{6}$ receptor antagonist, Ro 04-6790
}

Received: 25 November 2002 / Accepted: 26 May 2003 / Published online: 10 September 2003

(C) Springer-Verlag 2003

\begin{abstract}
Rationale: Accumulating evidence suggests a potential role for the $5-\mathrm{HT}_{6}$ receptor in cognitive function and the potential use of $5-\mathrm{HT}_{6}$ receptor antagonists in the treatment of learning and memory disorders. Objectives: The aim of the current study was to investigate the effect of the selective $5-\mathrm{HT}_{6}$ receptor antagonist, Ro 04-6790, on both the performance of normal adult rats and restoration of a pharmacological disruption of memory function produced by the non-selective muscarinic receptor antagonist, scopolamine, or the dopamine $\mathrm{D}_{2}$ receptor antagonist, raclopride, in a rodent model of recognition memory. Methods: Passive, perceptually based, recognition memory was assessed using a novel object discrimination task. Following habituation to an arena, rats were presented with two identical objects during trial $1\left(\mathrm{~T}_{1}\right)$ and a novel and familiar object during trial $2\left(\mathrm{~T}_{2}\right)$. The time spent exploring the two objects in each trial was measured and novel object discrimination assessed in $\mathrm{T}_{2}$. Results: In the absence of drug all rats spent an equal time exploring the two identical objects in $\mathrm{T}_{1}$ but more time exploring the novel object in $\mathrm{T}_{2}$. Scopolamine (but not $N$-methylscopolamine) and raclopride both produced a dose-dependent reduction in novel object discrimination whilst the $5-\mathrm{HT}_{6}$ receptor antagonist, Ro 04-6790, had no effect on discrimination when given alone but completely reversed the scopolamine- but not the raclopride-induced deficit. Conclusion: This study demonstrates that acute administration of Ro 04-6790
\end{abstract}

\section{L. Woolley · C. A. Marsden · K. C. F. Fone Institute of Neuroscience, School of Biomedical Science, Queen's Medical Centre, University of Nottingham, Nottingham, NG7 2UH, UK}

A. J. Sleight

PRBD-N, F. Hoffmann La-Roche, 4070 Basel, Switzerland

M. L. Woolley $(\bullet)$

Bau 72/129, PRBD-N, F. Hoffmann La-Roche,

4070 Basel, Switzerland

e-mail: Marie.Woolley@ roche.com

Tel.: +41-61-6870932

Fax: +41-61-6881895 reverses a cholinergic but not a dopaminergic deficit in a rodent model of recognition memory and provides further support for a role of the $5-\mathrm{HT}_{6}$ receptor in the regulation of cognitive function.

Keywords Memory $\cdot$ Rats $\cdot$ Ro 04-6790 $\cdot 5-\mathrm{HT}_{6}$ receptor antagonists

\section{Introduction}

The 5- $\mathrm{HT}_{6}$ receptor is one of the most recent additions to the fifteen mammalian 5-HT receptors identified to date (Hoyer et al. 2002). Following the discovery of the rodent 5- $\mathrm{HT}_{6}$ receptor using molecular biology (Monsma et al. 1993: Ruat et al. 1993), identification of the human analogue quickly followed (Kohen et al. 1996). These two receptor proteins comprise a linear chain of 438 (rat) and 440 (human) amino acids with a typical seven transmembrane spanning G-protein linked structure, are positively coupled to adenylyl cyclase and are $89 \%$ homologous. Research into the functional role of the receptor was initially hampered due to a lack of selective ligands and early studies made use of antisense oligonucleotides to reduce 5- $\mathrm{HT}_{6}$ receptor expression (Bourson et al. 1995; Bentley et al. 1997; Yoshioka et al. 1998; Hamon et al. 1999; Otano et al. 1999). However, recently a number of selective $5-\mathrm{HT}_{6}$ receptor antagonists have been characterized (Sleight et al. 1998; Bromidge et al. 1999; Issac et al. 2000; Lee et al. 2000; Tsai et al. 2000; Slassi et al. 2000; Bös et al. 2001; Russell et al. 2001), providing more selective tools with which to probe the functional role of this receptor. To date, the receptor has been implicated in psychotic disorders (Monsma et al. 1993; Roth et al. 1994; Tsai et al. 1999; Yu et al. 1999; Pouzet et al. 2002), affective disorders (Roth et al. 1994; Yau et al. 1997; Vogt et al. 2000), anxiety (Yoshioka et al. 1998; Hamon et al. 1999; Otano et al. 1999), epilepsy (Routledge et al. 2000) and potentially the regulation of food consumption (Bentley et al. 1997, 1999b; Woolley et al. 
2001), but the most compelling evidence suggests a role for the receptor in cognitive function.

Both chronic i.c.v. injection of a 5- $\mathrm{HT}_{6}$ receptor specific antisense oligonucleotide (A.O.; Bourson et al. $1995)$ and acute systemic administration of 4-amino- $\mathrm{N}$ $(2,6)$ bis-methyl-amino-pyrimidin-4-yl-benzene sulphonamide (Ro 04-6790, Bentley et al. 1999a) produced a specific behavioural syndrome of stretching, which was blocked by atropine but not by haloperidol, suggesting that the $5-\mathrm{HT}_{6}$ receptor may regulate central cholinergic, but not dopaminergic, neurotransmission. Consistent with this proposal, Ro 04-6790 blocked scopolamine-induced ipsilateral rotations but had no effect on apopmorphineinduced contralateral rotations in 6-hydroxydopamine (6OHDA) lesioned rats (Bourson et al. 1998). More recently, microdialysis studies have demonstrated elevated levels of acetylcholine in the hippocampus and frontal cortex of the conscious rat following treatment with either Ro 04-6790 (Shiraz-Southall et al. 2002) or the structural analogue Ro 65-7199 (Sleight et al. 1999). Given the well documented cholinergic link to memory function (Bartus et al. 1982), a 5- $\mathrm{HT}_{6}$ receptor-cholinergic interaction could account for the modulation of cognition seen with $5-\mathrm{HT}_{6}$ receptor antagonists.

We previously demonstrated enhanced retention (but not acquisition) of a learnt platform position in normal adult rats following chronic treatment with a specific 5$\mathrm{HT}_{6}$ receptor-directed A.O. and the selective 5- $\mathrm{HT}_{6}$ receptor antagonist, Ro 04-6790, after acquisition training in the Morris water maze (Bentley et al. 1997; Woolley et al. 2001). This was also seen with other $5-\mathrm{HT}_{6}$ receptor antagonists (5-chloro- $N$-(4-methoxy-3-piperazin-1-yl-phenyl)-3-methyl-2-benzothio-phene sulphonamide (SB271046) and N-(2,5-dibromo-3-fluorophenyl)-4-methoxy3-piperazin-1-yl benzene sulphonamide (SB-357134; Rogers et al. 1999; Rogers and Hagan 2001), suggesting that the $5-\mathrm{HT}_{6}$ receptor may regulate long-term memory in normal adult rats. More recently, Stean et al. (2002) demonstrated enhanced acquisition as measured by path length, in addition to enhanced retention of a learnt platform position in the Morris water maze following chronic administration of SB-357134 (10 mg/kg PO, twice daily, 7 days prior to training), implying a role for the 5$\mathrm{HT}_{6}$ receptor in both the learning and mnemonic processes involved in this spatial learning task. However, only few preliminary investigations have examined the effect of 5$\mathrm{HT}_{6}$ receptor antagonists on rodent models of impaired memory function, in order to determine their potential utility as therapeutic agents for the treatment of Alzheimer's disease (Rogers et al. 1999, 2000; Menses 2001).

Assessing passive perceptually based recognition memory, the novel object discrimination task takes advantage of the spontaneous preference of rodents for novelty and does not require reinforcement of behaviour by food reward. The latter aspect is of importance, since both i.c.v. injection of a 5- $\mathrm{HT}_{6}$-receptor directed A.O. (Bentley et al. 1997) and systemic injection of a selective 5- $\mathrm{HT}_{6}$ receptor antagonist Ro 04-6790 (Bentley et al. 1999b; Woolley et al. 2000) cause hypophagia that would confound interpretation of food motivated operant tasks (Meneses et al. 2001). Thus, using an ITI of $1 \mathrm{~min}$, the novel object discrimination task used in the current study assesses short-term recognition memory. Importantly, the pharmacological validity of the rodent novel object discrimination task to predict novel compounds with potential clinical advantage has also been demonstrated since Aricept (donepezil, E2020), currently used for the symptomatic relief in Alzheimer's disease, was found to reverse an age-related deficit in this task (Ni et al. 2001).

However, to date the neural substrates of novel object discrimination have not been conclusively defined. Several groups have suggested participation of the perirhinal and entorhinal cortices (Wiig and Bilkey 1995; Ennaceur et al. 1996, 1997; Aggleton et al. 1997; Ennaceur 1998), cortical association areas (Steckler et al. 1998) and the globus pallidus (Ennaceur 1998). In contrast, the role of the hippocampus is more controversial (Steckler et al. 1998). Thus, although electrolytic lesions of the septal-hippocampal pathway have no effect on novel object discrimination (Ennaceur 1998) conflicting results have been obtained following lesions of the fimbria-fornix pathway (Ennaceur and Aggleton 1994; Ennaceur et al. 1996, 1997; Mostafa and Ennaceur 2001) and radiofrequency lesions of the hippocampus (Clark et al. 2000; Aingie et al. 2002; Mumby et al. 2002). Yet, profound hippocampal lesion by ischaemia does induce impairment (Woods and Philips 1991), which becomes apparent with intertrial intervals between 1 and 10 min (Clark et al. 2000; Mumby et al. 2002), consistent with it being involved in recognition memory but not the appreciation of novelty per se. One possible explanation for this apparent disparity is that novel object discrimination impairment is only induced following severe hippocampal lesions and intertrial intervals of greater than $1 \mathrm{~min}$, as used herein.

The current study examines the effect of Ro 04-6790 on novel object discrimination, both when given alone and following the impairments induced by a muscarinic or a dopamine $\mathrm{D}_{2}$ receptor antagonist.

\section{Materials and methods}

\section{Animals and drug treatment}

Adult male Lister hooded rats (Biomedical Services Unit, University of Nottingham) weighing 200-400 g were housed in groups of four on a $12 \mathrm{~h}$ light/dark cycle (lights on $7.00 \mathrm{a} . \mathrm{m}$.) and given food and water ad libitum. Room temperature $\left(21 \pm 1^{\circ} \mathrm{C}\right)$ and humidity (55-65\%) were kept constant. Rats were randomly assigned to one of 14 treatment groups ( $n=10-12$ per group). Pretreatment comprised scopolamine hydrobromide $(0.1,0.5$ or $1 \mathrm{mg} / \mathrm{kg}$ IP), $\mathrm{N}$-methylscopolamine $(0.25$ or $0.5 \mathrm{mg} / \mathrm{kg} \mathrm{IP})$, raclopride L-tartrate $(0.1,0.3$ or $0.5 \mathrm{mg} / \mathrm{kg} \mathrm{IP})$, or physiological saline as the vehicle in all cases $(0.154 \mathrm{M}, 1 \mathrm{ml} / \mathrm{kg} \mathrm{IP})$. Twenty minutes later, rats were treated with either saline (IP), or the selective $5-\mathrm{HT}_{6}$ receptor antagonist Ro 04-6790 (10 or $30 \mathrm{mg} / \mathrm{kg}$ IP).

Each individual group of 10-12 rats was tested twice 7 days apart with a different pair of pretreatment/treatment conditions. On the second test, each rat was given the opposite pretreatment so that all rats received both treatments, such as saline and a chosen drug dose and thus served as their own control. Each rat was only re- 
tested once in order to avoid habituation to the two objects used for all studies. Further repeated testing with alternative objects was not performed, to avoid potential habituation to the task. All experiments were performed in accordance with the UK Animals (Scientific Procedures) Act 1986, by an observer who was unaware of the treatment given.

\section{Behavioural testing}

The novel object discrimination test used in the present study was a modification of that described by Ennaceur and Delacour (1988). The apparatus comprised a clear Perspex box as the arena, measuring $39 \times 23.5 \mathrm{~cm}$ with $30 \mathrm{~cm}$ high walls. The objects to be discriminated were plastic bottles $(8 \mathrm{~cm}$ high $\times 5 \mathrm{~cm}$ outer diameter) covered in white masking tape (familiar objects) or black and white striped masking tape (novel object). Each bottle was inverted and secured with Blue Tac through holes in the floor located 10 and $5 \mathrm{~cm}$ from either side and $5 \mathrm{~cm}$ from the end wall in opposite corners of the arena. The weight of each bottle was such that the rats could not displace it.

Twenty-four hours prior to testing, each rat was habituated to the arena for $60 \mathrm{~min}$ in the absence of any object. A total of 12 arenas were used and each rat was tested in the arena that it was habituated to. On test days, each group of rats received drug or saline pretreatment $20 \mathrm{~min}$ prior to the second drug or saline treatment and 20 min later testing began. Each rat was placed in the arena for $3 \mathrm{~min}$ in the absence of the objects for a second brief habituation period and then for two consecutive 3-min trial periods $\left(T_{1}\right.$ and $T_{2}$, respectively). All three encounters with the arena were separated by an inter-trial interval (ITI) of 1 min, during which the rat was returned to the home cage. In the first trial $\left(\mathrm{T}_{1}\right)$, rats were exposed to two objects of identical size, shape and pattern (objects $\mathrm{a}_{1}$ and $\left.\mathrm{a}_{2}\right)$. In the second trial $\left(\mathrm{T}_{2}\right)$ one of the bottles " $\mathrm{a}_{2}$ " was replaced with a bottle of identical size and shape but with alternating horizontal black and wipe stripes ("b", the novel object), whilst $\mathrm{a}_{1}$ was replaced with an object identical to those used in $\mathrm{T}_{1}$ (the familiar object, "a"). During $\mathrm{T}_{1}$ and $\mathrm{T}_{2}$ the exploration of either object was defined as the time spent (s) sniffing, licking, chewing or touching it with the nose or within $1 \mathrm{~cm}$ of it with moving vibrissae and was recorded separately for each object by stopwatch. Sitting on the object was not regarded as exploratory activity (but rarely occurred). Between each session, the bottles were wiped with $20 \%(\mathrm{v} / \mathrm{v})$ ethanol to remove any olfactory cues. Experiments were performed in constant light at 200 lux at floor level in the arena between 09.00 and 13.00 hours.

\section{Statistical analysis}

Within-group comparisons of time (s) spent exploring each of the two identical objects $\left(\mathrm{a}_{1}\right.$ and $\left.\mathrm{a}_{2}\right)$ in trial $1\left(\mathrm{~T}_{1}\right)$ and the novel (b) versus the familiar (a) objects in trial $2\left(\mathrm{~T}_{2}\right)$ were analysed using the Student's paired $t$-test. The effect of treatment on overall exploratory time in $T_{1}$ and $T_{2}$ and the time spent at the novel and familiar object was compared with their appropriate controls and also analysed using the Student's paired $t$-test.

\section{Materials}

Scopolamine hydrobromide and $N$-methylscopolamine, were purchased from Sigma Chemicals (Poole, Dorset, UK), raclopride Ltartrate from RBI chemicals (Poole, Dorset, UK), and Ro 04-6790 was a gift from F. Hoffmann La-Roche (Basel, Switzerland).

\section{Results}

Pretreatment with scopolamine hydrobromide

Following treatment with saline all three groups of rats spent an equal time exploring the two identical objects $\left(a_{1}\right.$ and $\left.\mathrm{a}_{2}\right)$ in the first trial $\left(\mathrm{T}_{1}\right.$, Table 1$)$, but a significantly
Table 1 Effect of increasing concentrations of the non-selective muscarinic antagonist, scopolamine hydrobromide, the quaternary amonium derivative, $N$-methylscopolamine, the dopamine $\mathrm{D}_{2}$ receptor antagonist, raclopride and the selective 5$\mathrm{HT}_{6}$ receptor antagonist, Ro 046790 , both given alone and as a combined treatment with scopolamine or raclopride, on the time spent ( $\mathrm{s}$, mean \pm SEM) exploring the two identical objects $\left(a_{1}\right.$ and $\left.a_{2}\right)$ in trial 1 . For each separate drug study, the saline data were pooled, as there was no significant difference between the groups

\begin{tabular}{|c|c|c|c|c|}
\hline Treatment group & Treatment (mg/kg IP) & $\begin{array}{l}\text { Number } \\
\text { of rats }\end{array}$ & $\begin{array}{l}\text { Total } \\
\text { exploration } \\
\text { of } \mathrm{a}_{1}(\mathrm{~s})\end{array}$ & $\begin{array}{l}\text { Total } \\
\text { exploration } \\
\text { of } a_{2}(s)\end{array}$ \\
\hline Scopolamine & $\begin{array}{l}\text { Saline } \\
0.1 \text { scopolamine } \\
0.5 \text { scopolamine } \\
1.0 \text { scopolamine }\end{array}$ & $\begin{array}{l}35 \\
12 \\
12 \\
11\end{array}$ & $\begin{array}{l}25 \pm 2 \\
26 \pm 3 \\
18 \pm 3 \\
19 \pm 3\end{array}$ & $\begin{array}{l}27 \pm 2 \\
29 \pm 2 \\
19 \pm 2 \\
20 \pm 8\end{array}$ \\
\hline$N$-Methylscopolamine & $\begin{array}{l}\text { Saline } \\
0.25 \text { scopolamine } \\
0.5 \text { scopolamine }\end{array}$ & $\begin{array}{l}24 \\
12 \\
12\end{array}$ & $\begin{array}{l}21 \pm 2 \\
14 \pm 3 \\
16 \pm 2\end{array}$ & $\begin{array}{l}22 \pm 1 \\
19 \pm 3 \\
16 \pm 3\end{array}$ \\
\hline Raclopride & $\begin{array}{l}\text { Saline } \\
0.1 \text { raclopride } \\
0.3 \text { raclopride } \\
0.5 \text { raclopride }\end{array}$ & $\begin{array}{l}36 \\
12 \\
12 \\
12\end{array}$ & $\begin{array}{l}24 \pm 1 \\
24 \pm 8 \\
16 \pm 2 \\
18 \pm 3\end{array}$ & $\begin{array}{l}21 \pm 3 \\
23 \pm 3 \\
17 \pm 1 \\
16 \pm 3\end{array}$ \\
\hline Ro 04-6790 & $\begin{array}{l}\text { Saline } \\
10 \text { Ro } 04-6790 \\
30 \text { Ro } 04-6790\end{array}$ & $\begin{array}{r}21 \\
12 \\
9\end{array}$ & $\begin{array}{l}31 \pm 2 \\
29 \pm 2 \\
21 \pm 5\end{array}$ & $\begin{array}{l}30 \pm 1 \\
29 \pm 2 \\
21 \pm 5\end{array}$ \\
\hline $\begin{array}{l}0.5 \text { scopolamine+ } \\
10 \text { Ro } 04-6790\end{array}$ & $\begin{array}{l}\text { Saline } \\
0.5 \text { scopolamine } \\
0.5 \text { scopolamine+10 Ro } 04-6790\end{array}$ & $\begin{array}{l}12 \\
24 \\
12\end{array}$ & $\begin{array}{l}17 \pm 2 \\
20 \pm 2 \\
23 \pm 2\end{array}$ & $\begin{array}{l}21 \pm 3 \\
21 \pm 1 \\
24 \pm 2\end{array}$ \\
\hline $\begin{array}{l}1.0 \text { scopolamine+ } \\
10 \text { Ro } 04-6790\end{array}$ & $\begin{array}{l}\text { Saline } \\
1.0 \text { scopolamine } \\
1.0 \text { scopolamine+10 Ro } 04-6790\end{array}$ & $\begin{array}{l}12 \\
24 \\
12\end{array}$ & $\begin{array}{l}25 \pm 3 \\
26 \pm 2 \\
27 \pm 2\end{array}$ & $\begin{array}{l}27 \pm 4 \\
27 \pm 2 \\
27 \pm 2\end{array}$ \\
\hline $\begin{array}{l}0.1 \text { raclopride+ } \\
10 \text { Ro 04-6790 }\end{array}$ & $\begin{array}{l}\text { Saline } \\
0.1 \text { raclopride } \\
0.1 \text { raclopride+10 Ro 04-6790 }\end{array}$ & $\begin{array}{l}12 \\
24 \\
12\end{array}$ & $\begin{array}{l}22 \pm 3 \\
22 \pm 2 \\
14 \pm 2\end{array}$ & $\begin{array}{l}19 \pm 2 \\
20 \pm 2 \\
13 \pm 1\end{array}$ \\
\hline $\begin{array}{l}0.3 \text { raclopride+ } \\
10 \text { Ro } 04-6790\end{array}$ & $\begin{array}{l}\text { Saline } \\
0.3 \text { raclopride } \\
0.3 \text { raclopride }+10 \text { Ro } 0-46790\end{array}$ & $\begin{array}{l}12 \\
24 \\
12\end{array}$ & $\begin{array}{l}21 \pm 1 \\
17 \pm 1 \\
20 \pm 1\end{array}$ & $\begin{array}{l}20 \pm 1 \\
18 \pm 1 \\
19 \pm 1\end{array}$ \\
\hline
\end{tabular}


A

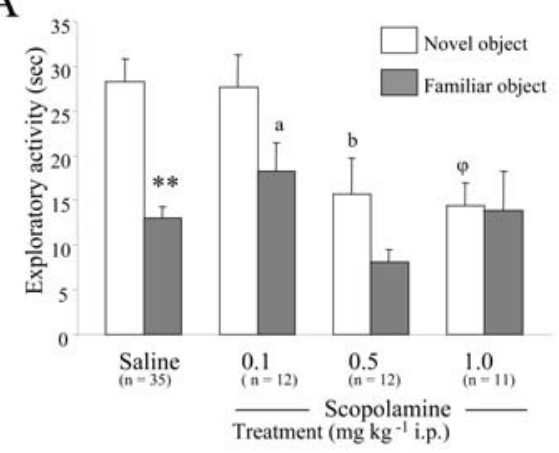

B

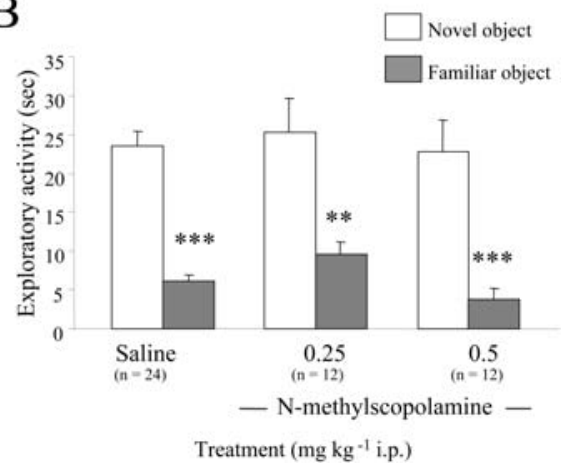

Fig. 1 Effect of increasing concentrations (as indicated, $\mathrm{mg} / \mathrm{kg}$, IP) of the non-selective muscarinic antagonist, scopolamine hydrobromide (A), the quaternary ammonium derivative, $N$-methylscopolamine $(\mathbf{B})$, the dopamine $\mathrm{D}_{2}$ receptor antagonist, raclopride $(\mathbf{C})$ and the selective 5- $\mathrm{HT}_{6}$ receptor antagonist, Ro 04-6790 (D), on the time spent (s, mean \pm SEM) exploring the novel versus the familiar object during trial 2 . Within each separate drug study, each group of rats received a single drug dose and saline separated by an

greater time exploring the novel (b) versus the familiar object (a) in the second trial $\left(\mathrm{T}_{2}, P<0.01\right.$, in each case, Fig. 1A), showing that they were able to discriminate the novel object during the choice trial. Following treatment with scopolamine $(0.1-1 \mathrm{mg} / \mathrm{kg} \mathrm{IP})$, all rats also spent an equal time exploring the two identical objects $\left(\mathrm{a}_{1}\right.$ and $\left.\mathrm{a}_{2}\right)$ in $\mathrm{T}_{1}$ (Table 1). However, scopolamine $(0.1,0.5$, and $1 \mathrm{mg} / \mathrm{kg}$ ) caused a dose-dependent impairment of novel object discrimination in $\mathrm{T}_{2}$, such that rats spent equivalent times exploring the novel and the familiar objects (Fig. 1A). This effect was most pronounced with the two higher doses of scopolamine, since the difference in time spent exploring the novel versus the familiar object following pretreatment with the lower dose of $(0.1 \mathrm{mg} / \mathrm{kg})$ scopolamine just missed significance $(P=0.07)$. Notably, scopolamine $(0.5$ and $1.0 \mathrm{mg} \mathrm{mg} / \mathrm{kg})$ tended to reduce the overall exploratory activity in $\mathrm{T}_{2}$, although when compared with saline treatment in the same rats, this did not reach significance. However, further analysis shows that scopolamine $(0.5$ and $1.0 \mathrm{mg} / \mathrm{kg})$ selectively reduced the time spent at the novel $(P=0.06$ for $0.5 \mathrm{mg} / \mathrm{kg}$ and $P<0.05$ for $1.0 \mathrm{mg} / \mathrm{kg}$ scopolamine) and not the familiar object when compared with saline pretreatment in the same rats (Fig. 1A). Thus 0.5 and $1.0 \mathrm{mg} / \mathrm{kg}$ were the doses of scopolamine chosen to examine the effect of Ro 04-6790
$\mathrm{C}$
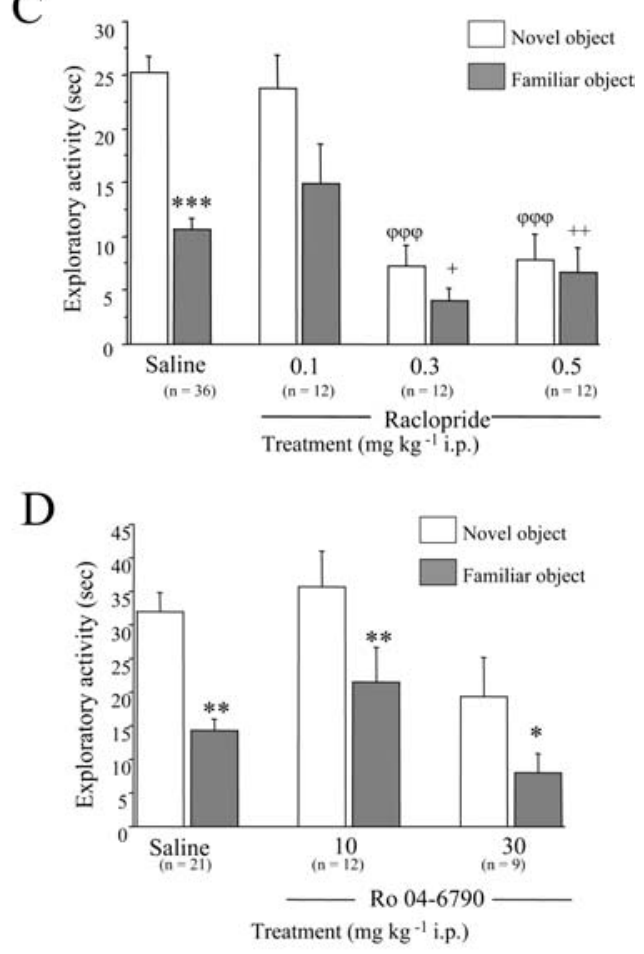

interval of 1 week and the saline data were pooled for clarity of presentation as there was no significant difference between the three groups. $* P<0.05$, $* * P<0.01$, $* * * P<0.001,{ }^{\text {a }} P=0.07$ compared with time spent at the novel object in the same treatment group. ${ }^{\phi} P<0.05,{ }^{\phi \phi \phi} P<0.001,{ }^{b} P=0.06$ compared with time spent exploring the novel object following saline treatment in the same group of rats. ${ }^{+} P<0.05,{ }^{++} P<0.01$ compared with time spent at the familiar object following saline treatment in the same group of rats

on a scopolamine-induced deficit in novel object discrimination.

Pretreatment with $N$-methylscopolamine

Following treatment with saline rats spent an equal time exploring the two identical objects during $T_{1}$ and significantly longer exploring the novel versus the familiar object during the choice trial $(P<0.001$, Fig. 1B). Similarly, following treatment with Nmethylscopolamine (both 0.25 and $0.5 \mathrm{mg} / \mathrm{kg}$ ), all rats spent an equal time exploring the two identical objects during $\mathrm{T}_{1}$ (Table 1). In contrast to scopolamine (above), treatment with $N$-methylscopolamine $(0.25$ or $0.5 \mathrm{mg} / \mathrm{kg})$, which does not penetrate into the CNS, had no effect on the ability of the rats to discriminate the novel object in $\mathrm{T}_{2}$. Thus all rats given $\mathrm{N}$-methylscopolamine, irrespective of dose, spent a significantly longer time exploring the novel versus the familiar object $(P<0.01$ for 0.25 and $P<0.001$ for $0.5 \mathrm{mg} / \mathrm{kg} N$-methylscopolamine, Fig. 1B) Notably, $N$-methylscopolamine also had no effect on total object exploration time in either trial (Table 2). 
Table 2 Effect of scopolamine, $\mathrm{N}$-methylscopolamine, raclopride and the $5-\mathrm{HT}_{6}$ antagonist, Ro 04-6790 at the doses indicated $(\mathrm{mg} / \mathrm{kg} \mathrm{IP})$ on total object exploration time (s, mean \pmSEM) in trial $1\left(\mathrm{~T}_{1}\right)$ and trial 2 $\left(\mathrm{T}_{2}\right)$ (i.e. the total time spent at the two familiar objects during $\mathrm{T}_{1}$ and the novel and familiar object during $\mathrm{T}_{2}$ ). For each separate drug study the saline data were pooled, as there was no significant difference between the groups

\begin{tabular}{lllll}
\hline Dose-response curve & $\begin{array}{l}\text { Treatment } \\
(\mathrm{mg} / \mathrm{kg} \mathrm{IP})\end{array}$ & $\begin{array}{l}\text { Number } \\
\text { of rats }\end{array}$ & $\begin{array}{l}\text { Total object } \\
\text { exploration } \\
\text { (s) in } \mathrm{T}_{1}\end{array}$ & $\begin{array}{l}\text { Total object } \\
\text { exploration } \\
\text { (s) in } \mathrm{T}_{2}\end{array}$ \\
\hline Scopolamine & Saline & 35 & $52 \pm 3$ & $41 \pm 3$ \\
& 0.1 scopolamine & 12 & $54 \pm 4$ & $46 \pm 4$ \\
& 0.5 scopolamine & 12 & $36 \pm 4$ & $24 \pm 5$ \\
$N$-Methylscopolamine & 1.0 scopolamine & 11 & $40 \pm 5$ & $28 \pm 7$ \\
& Saline & 24 & $43 \pm 3$ & $29 \pm 2$ \\
Raclopride & 0.25 scopolamine & 12 & $33 \pm 5$ & $37 \pm 6$ \\
& 0.5 scopolamine & 12 & $33 \pm 5$ & $23 \pm 4$ \\
& Saline & 36 & $46 \pm 2$ & $36 \pm 2$ \\
Ro 04-6790 & 0.1 raclopride & 12 & $46 \pm 5$ & $39 \pm 5$ \\
& 0.3 raclopride & 12 & $33 \pm 3^{*}$ & $11 \pm 3^{* *}$ \\
& 0.5 raclopride & 12 & $34 \pm 6^{*}$ & $15 \pm 5^{* * *}$ \\
& Saline & 21 & $62 \pm 3$ & $54 \pm 4$ \\
& 10 Ro 04-6790 & 12 & $58 \pm 4$ & $49 \pm 9$ \\
& 30 Ro 04-6790 & 9 & $50 \pm 8$ & $39 \pm 6$ \\
\hline
\end{tabular}

$* P<0.05, * * P<0.01$ and $* * * P<0.001$ compared with saline pretreatment in the same rats
Pretreatment with raclopride

As seen previously, following treatment with saline, rats spent an equal time exploring the two identical objects in the first trial $\left(\mathrm{T}_{1}\right.$, Table 1$)$ but a significantly greater time $(P<0.001)$ exploring the novel versus the familiar object in the second trial (Fig. 1C). In contrast, treatment with raclopride, irrespective of dose, impaired novel object discrimination in $\mathrm{T}_{2}$ (Fig. 1C) without altering the pattern of exploration in $\mathrm{T}_{1}$ (Table 1). Notably, pretreatment with raclopride $(0.3 \mathrm{mg} / \mathrm{kg}$ and $0.5 \mathrm{mg} / \mathrm{kg})$ also reduced the total exploratory activity in $\mathrm{T}_{1}$ when compared with that of saline pretreatment $(P<0.05$ for both groups, Table 2$)$. This effect was also seen in $\mathrm{T}_{2}(P<0.01$ for $0.3 \mathrm{mg} / \mathrm{kg}$ and $P<0.001$ for $0.5 \mathrm{mg} / \mathrm{kg}$, Table 2), and further analysis showed that raclopride reduced both the time spent exploring the novel $(P<0.001$ in both cases $)$ and the familiar object $(P<0.05$ for $0.3 \mathrm{mg} / \mathrm{kg}$ and $P<0.01$ for $0.5 \mathrm{mg} / \mathrm{kg}$, Fig. 1C) in $\mathrm{T}_{2}$, suggesting that these doses caused a non-selective reduction in exploration rather than a selective attenuation of working memory. Thus the lower doses $(0.1$ and $0.3 \mathrm{mg} / \mathrm{kg})$ of raclopride were chosen to examine the effect of Ro 04-6790 on a raclopride-induced deficit in novel object discrimination.

\section{Treatment with Ro 04-6790}

Following treatment with saline, both groups of rats spent an equivalent time exploring the two familiar objects during $\mathrm{T}_{1}$ (Table 1) but significantly longer exploring the novel versus the familiar object during $\mathrm{T}_{2}(P<0.01$, Fig. 1D). Treatment with Ro 04-6790 had no effect on novel object discrimination, such that even following the highest dose $\left(30 \mathrm{mg} / \mathrm{kg}\right.$ ) of this $5-\mathrm{HT}_{6}$ antagonist, rats spent an equal time exploring the two identical objects in $\mathrm{T}_{1}$ (Table 1) and significantly longer exploring the novel versus the familiar object in $\mathrm{T}_{2}(P<0.01$ for $10 \mathrm{mg} / \mathrm{kg}$ Ro $04-6790$ and $P<0.05$ for $30 \mathrm{mg} / \mathrm{kg}$ Ro 04-6790, Fig. 1D). Thus, Ro 04-6790 had no effect on the ability of the rats to discriminate the novel object in $\mathrm{T}_{2}$. In contrast to the effect of the lowest dose of
Ro 04-6790, treatment with $30 \mathrm{mg} / \mathrm{kg}$ tended to reduce total object exploration time during $\mathrm{T}_{2}$ (Table 2), but this did not reach significance.

Ro 04-6790 reverses a scopolamine- but not a racloprideinduced deficit in novel object discrimination

As expected from the dose-response study, pretreatment with both 0.5 and $1 \mathrm{mg} / \mathrm{kg}$ scopolamine impaired the ability of the rats to discriminate the novel from the familiar object in $\mathrm{T}_{2}$ (Fig. 2A, B), without altering the pattern of exploration in $\mathrm{T}_{1}$ (Table 1), such that in both cases rats spent an equal time exploring the novel and familiar objects in the choice trial. However, in both cases, treatment with Ro 04-6790 (10 mg/kg IP) completely reversed the scopolamine-induced deficit in novel object discrimination (Fig. 2A, B) such that rats receiving combined treatment of scopolamine $(0.5$ or $1.0 \mathrm{mg} / \mathrm{kg})$ and Ro 04-6790 spent a significantly longer time exploring the novel versus the familiar object in $\mathrm{T}_{2}$ $(P<0.01$ for $0.5 \mathrm{mg} / \mathrm{kg}$ scopolamine + Ro $04-6790$ and $P<0.001$ for $1.0 \mathrm{mg} / \mathrm{kg}$ scopolamine + Ro 04-6790).

Notably, when given in combination with scopolamine $(0.5 \mathrm{mg} / \mathrm{kg})$ in $\mathrm{T}_{2}$, Ro 04-6790 $(10 \mathrm{mg} / \mathrm{kg})$ increased the total exploratory activity compared with that in the same rats receiving scopolamine alone $(P<0.05$, Table 3$)$. Although it failed to reach significance, Ro 04-6790 produced a similar increase in the response in rats receiving the higher dose of scopolamine $(1.0 \mathrm{mg} / \mathrm{kg}$, Table 3). Further analysis showed that in both cases, this effect was accounted for by a significant increase in time spent exploring the novel object during $\mathrm{T}_{2}(P<0.05$ in both cases, Fig. 2A and 2B) following combined treatment with scopolamine and Ro 04-6790, consistent with the rats selectively redirecting their exploration towards the novel object in the choice trial.

As expected from the dose-response curve (Fig. 1C), pretreatment with raclopride $(0.3 \mathrm{mg} / \mathrm{kg}$ IP $)$ abolished novel object discrimination in $\mathrm{T}_{2}$ (Fig. 3B) without altering the pattern of object exploration in $\mathrm{T}_{1}$ (Table 1 ). 
A

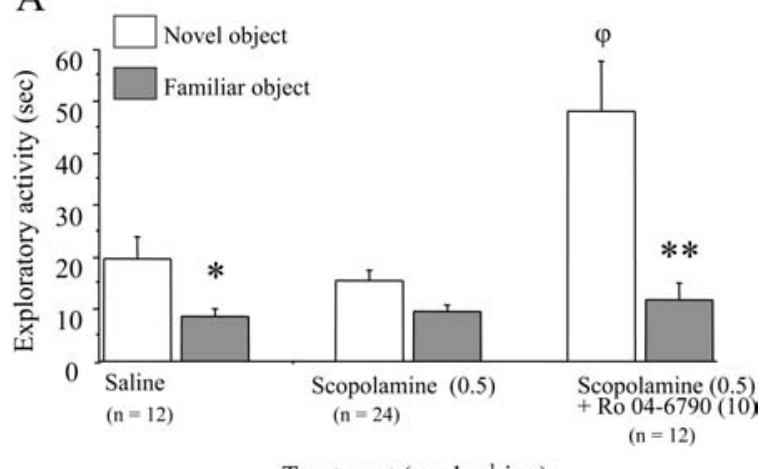

Treatment ( $\mathrm{mg} \mathrm{kg}^{-1}$ i.p.)

B

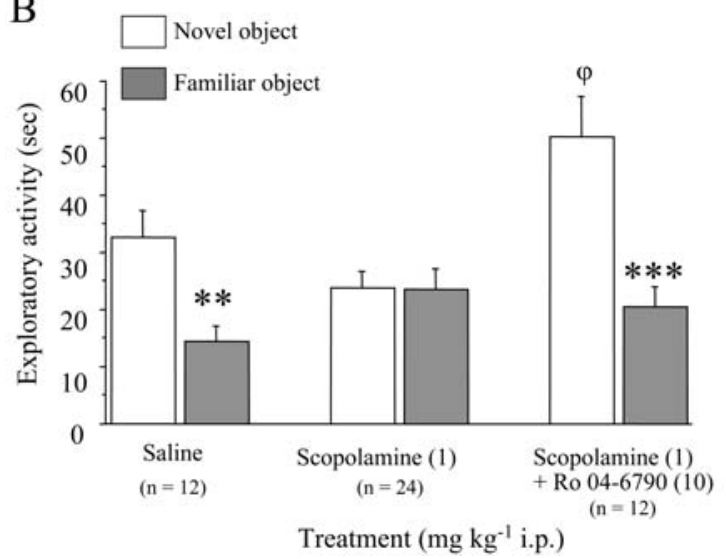

Fig. 2 Effect of combined treatment with Ro 04-6790 (10 mg/kg IP) and $0.5 \mathrm{mg} / \mathrm{kg}$ IP scopolamine (A) or $1 \mathrm{mg} / \mathrm{kg}$ IP scopolamine (B) on the time spent ( $\mathrm{s}$, mean \pm SEM) exploring the novel versus the familiar object during trial 2. Within each of the studies the two groups of rats received either scopolamine and saline or scopolamine and Ro 04-6790 separated an interval of 1 week. For clarity of presentation the data from the two groups were pooled for each drug. $* P<0.05$, $* * P<0.01$, $* * * P<0.001$ compared with time spent at the novel object in the same treatment group. ${ }^{\phi} P<0.05$ compared with time spent exploring the novel object following treatment with scopolamine alone in the same rats

Table 3 Effect of scopolamine $(0.5$ and $1.0 \mathrm{mg} / \mathrm{kg} \mathrm{IP})$ or raclopride $(0.1$ or $0.3 \mathrm{mg} / \mathrm{kg} \mathrm{IP})$ either given alone or as a combined treatment with Ro 04-6790 (10 mg/kg IP) on the total object exploration time
A
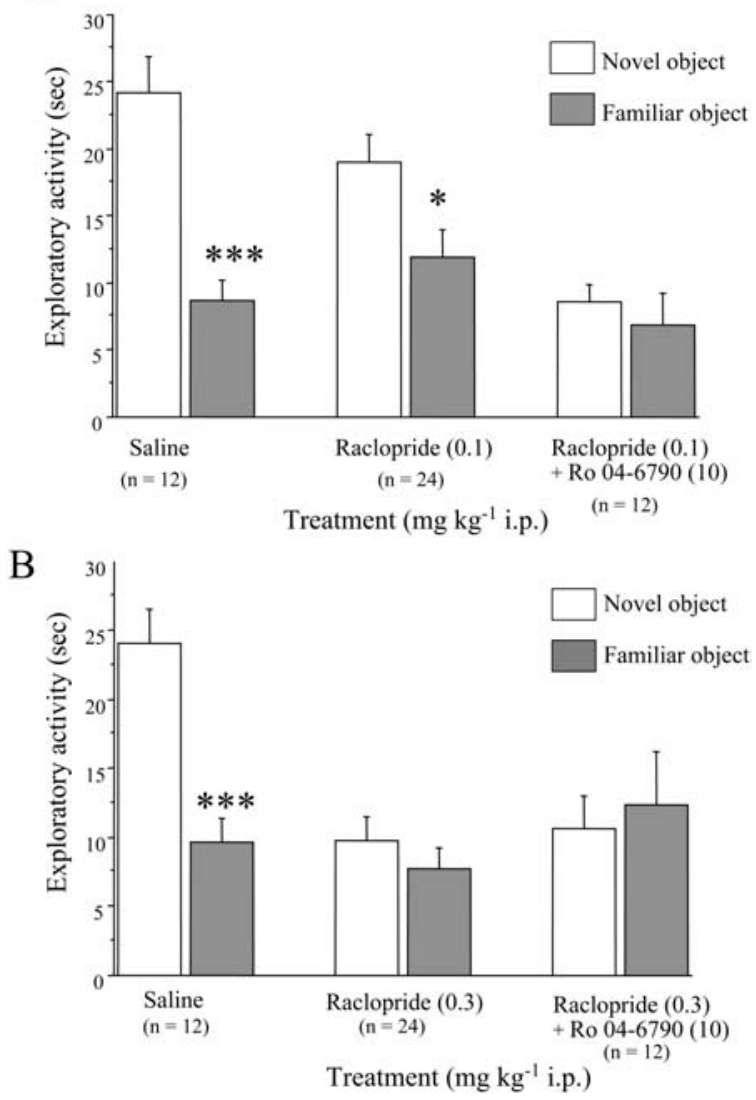

Fig. 3 Effect of combined treatment with Ro 04-6790 (10 mg/kg IP) and $0.1 \mathrm{mg} / \mathrm{kg}$ IP raclopride (A) or $0.3 \mathrm{mg} / \mathrm{kg}$ IP raclopride (B) on the time spent $(\mathrm{s}$, mean \pm SEM) exploring the novel versus the familiar object during trial 2. Within each of the studies each group of rats received either raclopride and or raclopride and Ro 04-6790 separated by an interval of 1 week. For clarity of presentation, the data from the two groups were pooled for each drug. $* P<0.05$, $* * * P<0.001$ compared with time spent at the novel object in the same treatment group

[total time spent at both objects $(\mathrm{s}$, mean $\pm \mathrm{SEM})]$ in trial $1\left(\mathrm{~T}_{1}\right)$ and trial $2\left(\mathrm{~T}_{2}\right)$

\begin{tabular}{|c|c|c|c|c|}
\hline Treatment group & Treatment (mg/kg IP) & $\begin{array}{l}\text { Number } \\
\text { of rats }\end{array}$ & $\begin{array}{l}\text { Total object } \\
\text { exploration } \\
\text { (s) in } \mathrm{T}_{1}\end{array}$ & $\begin{array}{l}\text { Total object } \\
\text { exploration } \\
\text { (s) in } \mathrm{T}_{2}\end{array}$ \\
\hline 0.5 scopolamine+10 Ro $04-6790$ & $\begin{array}{l}\text { Saline } \\
0.5 \text { scopolamine } \\
0.5 \text { scopolamine+10 Ro } 04-6790\end{array}$ & $\begin{array}{l}12 \\
24 \\
12\end{array}$ & $\begin{array}{l}38 \pm 4 \\
41 \pm 3 \\
47 \pm 3\end{array}$ & $\begin{array}{l}28 \pm 4 \\
25 \pm 3 \\
60 \pm 9 *\end{array}$ \\
\hline 1.0 scopolamine+10 Ro $04-6790$ & $\begin{array}{l}\text { Saline } \\
1.0 \text { scopolamine } \\
1.0 \text { scopolamine+10 Ro } 04-6790\end{array}$ & $\begin{array}{l}12 \\
24 \\
12\end{array}$ & $\begin{array}{l}51 \pm 7 \\
50 \pm 3 \\
54 \pm 4\end{array}$ & $\begin{array}{l}47 \pm 7 \\
47 \pm 6 \\
71 \pm 9\end{array}$ \\
\hline 0.1 raclopride+10 Ro $04-6790$ & $\begin{array}{l}\text { Saline } \\
0.1 \text { raclopride } \\
0.1 \text { raclopride+10 Ro 04-6790 }\end{array}$ & $\begin{array}{l}12 \\
24 \\
12\end{array}$ & $\begin{array}{l}47 \pm 5 \\
42 \pm 3 \\
26 \pm 2\end{array}$ & $\begin{array}{l}33 \pm 3 \\
31 \pm 3 \\
15 \pm 3\end{array}$ \\
\hline 0.3 raclopride +10 Ro $04-6790$ & $\begin{array}{l}\text { Saline } \\
0.3 \text { raclopride } \\
0.3 \text { raclopride+10 Ro } 04-6790\end{array}$ & $\begin{array}{l}12 \\
24 \\
12\end{array}$ & $\begin{array}{l}41 \pm 2 \\
36 \pm 2 \\
39 \pm 2\end{array}$ & $\begin{array}{l}34 \pm 3 \\
18 \pm 3 \\
23 \pm 6\end{array}$ \\
\hline
\end{tabular}

$* P<0.05$, compared with scopolamine treatment alone in the same rats 
Similarly, rats receiving combined treatment with raclopride $(0.3 \mathrm{mg} / \mathrm{kg})$ and Ro 04-6790 $(10 \mathrm{mg} / \mathrm{kg})$ were also unable to discriminate the novel from the familiar object and spent an equal time at the two objects in $\mathrm{T}_{2}$ (Fig. 3B). Conversely pretreatment with the lower dose $(0.1 \mathrm{mg} / \mathrm{kg})$ of raclopride did not impair novel object discrimination but combined treatment of 0.1 raclopride and Ro 04-6790 further attenuated, and led to a significant impairment of, novel object discrimination (Fig. 3A). Thus, in contrast to the results seen with scopolamine, Ro 04-6790 did not reverse the raclopride-induced deficit in novel object discrimination.

\section{Discussion}

The aim of the present study was to investigate the effect of the selective 5- $\mathrm{HT}_{6}$ receptor antagonist, Ro 04-6790, both when given alone and following a pharmacologically induced deficit in a rodent model of short term recognition memory, the novel object discrimination task. Acute systemic injection of Ro 04-6790 had no effect on novel object discrimination when given alone but it totally reversed the deficit induced following blockade of muscarinic but not dopamine $\mathrm{D}_{2}$ receptors.

The centrally active, non-selective muscarinic receptor antagonist, scopolamine, has been widely used to demonstrate the cholinergic involvement in memory and cognition in rodents. Peripheral administration of scopolamine produces deficits in a variety of spatial tests such as the delayed matching to position (Dunnett 1985) and the Morris water maze (Harder et al. 1996). In addition, deficits in non-spatial working memory tests such as spontaneous alternation (Pontecorvo et al. 1991), novel object discrimination (Ennaceur and Meliani 1992) and continuous non-matching tasks (Wan et al. 1997) occur following muscarinic antagonist administration. Consistent with these findings, pretreatment with scopolamine at doses equivalent to those used in the aforementioned studies (Dunnett 1985; Ennaceur and Meliani 1992) also produced impaired novel object discrimination in the current study. In contrast, acute, systemic injection of the quaternary ammonium derivative $N$-methylscopolamine, that does not penetrate the blood-brain barrier and therefore has no CNS activity, had no effect on novel object discrimination, consistent with previous reports (Dunnett 1985; Ennaceur and Meliani 1992). Taken together, this suggests that the deficit in novel object discrimination seen with scopolamine is mediated via central muscarinic receptor blockade and not due to a parasympatholytic effect on visual acuity.

In accordance with previous studies demonstrating attenuation of working memory in both spatial (Wilkerson and Levin 1999; Umegaki et al. 2001) and non-spatial tasks (Didriksen 1995), the selective dopamine $D_{2}$ receptor antagonist raclopride also caused a dose-dependent impairment of novel object discrimination. This is consistent with the proposed role of dopamine $\mathrm{D}_{2}$ receptors in the regulation of memory (Noyce et al.
1993). However, the deficit in novel object discrimination seen following treatment with the highest dose $(0.3 \mathrm{mg} /$ $\mathrm{kg}$ ) of raclopride was also accompanied by a reduction in total object exploration, in both trials 1 and 2. Thus, in the current study it seems that the deficit in novel object discrimination seen with raclopride was a consequence of the characteristic hypolocomotor effect of dopamine $\mathrm{D}_{2}$ receptor antagonists (Jackson and Westlind-Danielsson 1994; Feldman et al. 1997), rather than a selective attenuation of recognition memory.

The selective 5- $\mathrm{HT}_{6}$ receptor antagonist Ro 04-6790 has been shown to have over 100-fold selectivity for the $5-\mathrm{HT}_{6}$ receptor compared with 24 other G-protein coupled receptors, including all muscarinic, dopamine and eight other 5-HT receptors (Sleight et al. 1998). When given alone, Ro 04-6790, had no effect on the ability of the rats to perform discrimination of a novel object. However, it completely reversed the deficit in novel object discrimination produced by scopolamine, suggesting that blockade of $5-\mathrm{HT}_{6}$ receptors increases cholinergic function sufficiently to overcome central muscarinic receptor blockade, probably by increasing acetylcholine release (Sleight et al. 1999; Shirizai-Southall et al. 2002). Conversely, Ro 04-6790 did not reverse the dopamine $\mathrm{D}_{2}$ receptor antagonist-induced deficit in the same task, consistent with previous data indicating that the $5-\mathrm{HT}_{6}$ receptor does not modulate central dopaminergic neurotransmission (Bourson et al. 1995, 1998; Bentley et al. 1999a; Dawson et al. 2000, 2001). Since $\mathrm{D}_{2}$ dopamine receptor blockade following treatment with raclopride in the current study produces a non-selective reduction in exploratory behaviour, the fact that Ro 04-6790 did not reverse this non-specific behavioural disturbance, but did reverse a selective reduction in novel object discrimination following scopolamine, further supports a role for the $5-\mathrm{HT}_{6}$ receptor in memory processes.

Consistent with the data in the current study, several lines of evidence suggest that $5-\mathrm{HT}_{6}$ receptors regulate central cholinergic neurotransmission. For instance, both 5-HT 6 -directed A.O. (Bourson et al. 1995) and Ro 046790 (Sleight et al. 1998) produced yawning, stretching and chewing that was antagonised by the muscarinic receptor antagonists atropine and scopolamine (Bourson et al. 1995; Bentley et al. 1999a). Routledge et al. (1999) also demonstrated that another $5-\mathrm{HT}_{6}$ antagonist, SB271046 (Bromidge et al. 1999), enhanced physostigmineinduced yawning. Since the behavioural responses were seen after treatment with a $5-\mathrm{HT}_{6}$ receptor-directed A.O. or a selective antagonist, it has been proposed that this receptor receives tonic serotonergic input or possesses constitutive activity (Bourson et al. 1995). Furthermore, after unilateral 6-OHDA lesions of the medial forebrain bundle, both atropine- and scopolamine-induced ipsilateral rotations, but not dopamine-induced contralateral rotations, were inhibited by Ro 04-6790 (Bourson et al. 1998). In agreement with a $5-\mathrm{HT}_{6}$ receptor-cholinergic interaction in the regulation of cognition, Meneses (2001) demonstrated that Ro 04-6790 (5 mg/kg IP) reversed a scopolamine-induced deficit in learning consolidation in 
an autoshaping paradigm. Furthermore, two preliminary intracerebral microdialysis reports suggest that Ro 046790 and the structural analogue Ro 65-7199, increase cortical and hippocampal extracellular acetylcholine levels (Sleight et al. 1999; Shirazi-Southall et al. 2002, respectively) and reverse scopolamine-induced deficits in the Morris water maze and passive avoidance tests (Sleight et al. 1999; Bös et al. 2001).

Whilst the present study demonstrates a $5-\mathrm{HT}_{6}$ receptor-cholinergic interaction, the way in which $5-\mathrm{HT}_{6}$ receptor blockade increases acetylcholine release is currently unknown. By using an N-terminal directed specific antibody, we previously characterised the distribution of $5-\mathrm{HT}_{6}$-like immunoreactivity $\left(5-\mathrm{HT}_{6}-\mathrm{LI}\right)$ in the rat brain (Woolley et al. 2000). The overall pattern matched that reported using a C-terminal directed antibody (Gérard et al. 1997) and the selective radioligand [ $\left.{ }^{125} \mathrm{I}\right]$ 4-iodo-N-[4-methoxy-3-(4-methylpiperazin-1yl)phenyl]benzenesulfonamide (SB-258585, Roberts et al. 2002), demonstrating abundant $5-\mathrm{HT}_{6}$ receptor protein in several of the neural areas implicated in the novel object discrimination task, including the cortex and hippocampus (Steckler et al. 1998; Clark et al. 2000; Mumby et al. 2002). Furthermore, by using dual labelled immunohistochemistry, very low levels of co-existence were found between the $5-\mathrm{HT}_{6}$ receptor and choline acetyltransferase (ChAT)-LI (Woolley et al. 2000) limited to few discrete brain regions, including the medial septal nuclei ( $17 \%$ of $5-\mathrm{HT}_{6}$ positive neurones) caudate nucleus (19\%), nucleus accumbens (16\%) and some areas of the cortex $(5-8 \%$ in the cingulate, frontal and parietal corticies). Taken together, these data suggest that whilst a direct $5-\mathrm{HT}_{6}$ receptor activation of cholinergic neurones may occur in these areas, in some regions the predominant form of interaction may not be direct. Conversely, abundant and extensive co-existence was seen between 5$\mathrm{HT}_{6}-\mathrm{LI}$ and $\mathrm{GAD}_{67}-\mathrm{LI}$, a marker of GABAergic neurones in 29 out of the 42 brain regions examined (Woolley et al. 2000). Such co-existence is in accordance with previous evidence of $5-\mathrm{HT}_{6}$ receptor-GABA co-existence in the striatum (Ward and Dorsa 1996; Gérard et al. 1997), and suggests that this may be an important method of interaction. Therefore, the $5-\mathrm{HT}_{6}$ receptor-regulation of cholinergic neurotransmission may occur via inhibition of GABA and thence disinhibition of acetylcholine release, as previously described for the $5-\mathrm{HT}_{3}$ receptor (Ramirez et al. 1996; Diez-Ariza et al. 1998).

Interestingly, Dawson et al. (2001) recently demonstrated that the 5- $\mathrm{HT}_{6}$ receptor antagonist, SB-271046, caused a tetrodotoxin-sensitive increase in extracellular glutamate release by microdialysis in the frontal cortex and dorsal hippocampus (but not in the striatum or nucleus accumbens) of conscious adult rats. Furthermore, Meneses (2001) demonstrated that Ro 04-6790 partially reversed an impairment in learning consolidation produced by the NMDA receptor antagonist, dizocilpine, consistent with the idea that $5-\mathrm{HT}_{6}$ receptor-modulation of glutamate may also contribute to the effect of $5-\mathrm{HT}_{6}$ receptor antagonists on memory processing. Interestingly, serotonergic median raphé afferents preferentially innervate inhibitory GABAergic interneurones in the hippocampus and dentate gyrus (Freund et al. 1990; Freund 1992) and thus is consistent with the proposal that $5-\mathrm{HT}_{6}$ receptor regulation of glutamate may occur indirectly via inhibition of GABA in this area. Indeed, Dawson et al. (2001) showed that cholinergic-regulation of glutamate release in this area is unlikely, since atropine had no effect on SB-271046-induced extracellular glutamate release. However, the possibility that cholinergic neurotransmission increases as a result of elevated glutamatergic neurotransmission has not been investigated in this region and cannot be ruled out, since cholinergic interneurones are present, albeit at low levels (Vizi and Kiss 1998), and such an interaction has been demonstrated in the rat striatum (Consolo et al. 1996).

In summary, the current study demonstrates that acute systemic administration of Ro 04-6790 selectively reverses a cholinergic-induced deficit in a rodent model of short term recognition memory. Whilst the underlying mechanism of action remains to be elucidated the current findings add further support for a role of the 5- $\mathrm{HT}_{6}$ receptor in the regulation of memory processes.

Acknowledgements M.L.W. was an MRC case student supported by F. Hoffman-La Roche, who provided Ro 04-6790.

\section{References}

Aggleton JP, Keen S, Warburton EC, Bussey TJ (1997) Extensive cytotoxic lesions involving both the rhinal corticies and are TE impair recognition but spare alternation in the rat. Brain Res Bull 43:279-287

Ainge JA, Heron-Maxwell C, Wright PG, de Hoz L, Wood ER (2002) Comparison of complete and partial lesions in rats on spontaneous object recognition and spatial water maze performance. Soc Neurosci Abstr 585.5

Bartus RT, Dean RL, Beer B, Lippa AS (1982) The cholinergic hypothesis of geriatric memory dysfunction. Science 217:408417

Bentley JC, Sleight AJ, Marsden CA, Fone KCF (1997) 5-HT 6 antisense oligonucleotide ICV affects rat performance in the water maze and feeding. J Psychopharmacol 11:A64

Bentley JC, Bourson A, Boess FG, Fone KCF, Marsden CA, Petit N, Sleight AJ (1999a) Investigation of stretching behaviour induced by the selective $5-\mathrm{HT}_{6}$ receptor antagonist Ro 046790:in rats. Br J Pharmacol 126:1537-1542

Bentley JC, Marsden CA, Sleight AJ, Fone KCF (1999b) Effect of the 5- $\mathrm{HT}_{6}$ antagonist, Ro 04-6790 on food consumption in rats trained to a fixed feeding regime. Br J Pharmacol 126:66P

Bös M, Sleight AJ, Godel T, Martin JR, Reimer C, Stadler H (2001) $5-\mathrm{HT}_{6}$ receptor antagonists: lead optimisation and biological evaluation of n-aryl and -heteroaryl 4-amino-benzene sulfonamides. Eur J Med Chem 36:165-178

Bourson A, Borroni E, Austin RH, Monsma FJ Jr, Sleight AJ (1995) Determination of the role of the 5- $\mathrm{HT}_{6}$ receptor in the rat brain: a study using antisense oligonucleotides. J Pharmacol Exp Ther 274:173-180

Bourson A, Boess FG, Bos M, Sleight AJ (1998) Involvement of 5$\mathrm{HT}_{6}$ receptors in nigro-striatal function in rodents. $\mathrm{Br} \mathrm{J}$ Pharmacol 125:1562-1566

Bromidge SM, Brown AM, Clarke SE, Dodgson K, Gager T, Grassam HL, Jeffrey PM, Joiner GF, King FD, Middlemiss DN, Moss SF, Newman H, Riley G, Routledge C, Wyman P (1999) 5-Chloro-N-(methoxy-3-piperazin-1-yl-phenyl)-3-methyl-2- 
benzothiophene-sulfonamide (SB-271046): a potent, selective and orally bioavailable 5- $\mathrm{HT}_{6}$ receptor antagonist. J Med Chem 42:202-205

Clark RE, Zola SM, Squire LR (2000) Impaired recognition memory in rats after damage to the hippocampus. J Neurosci 20:8853-8860

Consolo S, Baldi G, Giorgi S, Nannini L (1996) The cerebral cortex and parafasicular thalamic nucleus facilitate in vivo acetylcholine release in the rat striatum through distinct glutamate receptor subtypes. Eur J Neurosci 8:2702-2710

Dawson LA, Nguyen HQ, Li P (2000) In vivo effects of the 5-HT 6 antagonist, SB-271046 on striatal and frontal cortex extracellular concentrations of noradrenaline, dopamine, 5-HT, glutamate and aspartate. Br J Pharmacol 130:23-26

Dawson LA, Nguyen HQ, Li P (2001) The 5-HT 6 receptor antagonist SB-271046 selectively enhances excitatory neurotransmission in the rat frontal cortex and hippocampus. Neuropsychopharmacology 25:662-668

Didriksen M (1995) Effects of antipsychotics on cognitive behaviour in rats using the delayed non-match to position paradigm. Eur J Pharmacol 281:241-250

Diez-Ariza M, Ramirez MJ, Lasheras B, Del Rio J (1998) Differential interaction between 5- $\mathrm{HT}_{3}$ receptors and GABAergic neurons inhibiting acetylcholine release in rat entorhinal cortex slices. Brain Res 801:228-232

Dunnett SB (1985) Comparative effects of cholinergic drugs and lesions of the nucleus basalis or fimbria-fornix on delayed matching in rats. Psychopharmacology 87:357-363

Ennaceur A (1998) Effects of lesions of the substantia innominata ventra pallidum, globus pallidus and medial septum on rat's performance in object-recognition and radial-maze tasks: physostigmine and amphetamine treatments. Pharmacol Res $38: 251-263$

Ennaceur A, Aggleton JP (1994) Spontaneous recognition of object configurations in rats-effects of fornix lesions. Exp Brain Res 100:85-92

Ennacuer A, Delacour J (1988) A new one-trial test for neurobiological studies of memory in rats. I: Behavioural data. Behav Brain Res 31:47-59

Ennaceur A, Meliani K (1992) Effects of physostigmine and scopolamine on rats' performances in object-recognition and radial-maze tests. Psychopharmacology 109:321-330

Ennaceur A, Neave N, Aggleton JP (1996) Neurotoxic lesions of the perirhinal cortex do not mimic the behavioural effects of fornix transection in the rat. Behav Brain Res 80:9-25

Ennaceur A, Neave N, Aggleton JP (1997) Spontaneous object recognition and object location memory in rats: the effects of lesions in the cingulate cortices, the medial prefrontal cortex, the cingulum bundle and the fornix. Exp Brain Res 113:509519

Feldman RS, Meyer JS, Quenzer LF (1997) Catecholamines: In: Principles of neuropsychopharmacology. Sinauer, Sunderland, Mass., pp 277-344

Freund TF (1992) GABAergic septal and serotonergic median raphé afferents preferentially innervate inhibitory interneurones in the hippocampus and dentate gyrus. Epilepsy Res Suppl 7:79-91

Freund TF, Gulyas AI, Acsady L, Gorcs T, Toth K (1990) Serotonergic control of the hippocampus via local inhibitory interneurones. Proc Natl Acad Sci USA 87:8501-8505

Gérard C, Martres MP, Lefevre K, Miquel M-C, Verge D, Lanfumey L, Doucet E, Hamon M, El Mestikaway S (1997) Immuno-localization of serotonin 5- $\mathrm{HT}_{6}$ receptor-like material in the rat central nervous system. Brain Res 746:207-219

Hamon MH, Doucet E, Lefévre K, Miquel M-C, Lanfumey L, Insausti R, Frechill D, Del Rio J, Vergé D (1999) Antibodies and antisense oligonucleotide for probing the distribution and putative functions of central 5- $\mathrm{HT}_{6}$ receptors. Neuropsychopharmacology 21:68S-76S

Harder JA, Kelly ME, Cheng CHK, Costall B (1996) Combined pCPA and muscarinic antagonist treatment produced a deficit in rat water maze acquisition, Pharmacol Biochem Behav 55:61-65

Hoyer D, Hannon JP, Martin GR (2002) Molecular, pharmacological and functional diversity of 5-HT receptors. Pharmacol Biochem Behav 71:533-554

Issac M, Slassi A, Xin T, Maclean N, Wilson J, McCallum K, Wang H, Demchyshyn L (2000) 6-Bicyclopiperazinyl-1-arylsulfonylindoes and 6-Bicyclopiperidinyl-1-arylsufony-lindoles derivatives as novel, potent, and selective 5- $\mathrm{HT}_{6}$ receptor antagonists. Bioorg Med Chem Lett 10:1719-1721

Jackson DM, Westlind-Danielsson A (1994) Dopamine receptors: molecular biology, biochemistry and behavioural aspects. Pharmacol Ther 64:291-370

Kohen R, Metcalf MA, Khan N, Druck T, Huebner K, Lachowicz JE, Meltzer HY, Sibley DR, Roth BL, Hamblin MW (1996) Cloning, characterisation and chromosomal location of a human 5- $\mathrm{HT}_{6}$ serotonin receptor. J Neurochem 66:47-56

Lee M, Ragisetty JB, Dukat M, Slassi A, Maclean N, Lee DKH, Glennon RA (2000) 5- $\mathrm{HT}_{6}$ serotonin receptor bindings affinities of N1-benzenesulfonyl and related tryptamines. Med Chem Res 10:230-242

Meneses A (2001) Effects of the 5- $\mathrm{HT}_{6}$ receptor antagonist Ro 046790 on learning consolidation. Behav Brain Res 118:107-110

Monsma FJ Jr, Shen Y, Ward RP, Hamblin MW, Sibley DR (1993) Cloning and expression of a novel serotonin receptor with high affinity for tricyclic psychotropic drugs. Mol Pharmacol 43:320-327

Mostafa R, Ennaceur A (2001) Fornix lesions impair both spatial and non-spatial memory in rats: space vs. featureless objects. Eur J Neurosci 12:252S

Mumby DG, Gaskin S, Glenn MJ, Schramek TE, Lehmann H (2002) Hippocampal damage and exploratory preferences in rats: memory for objects, places, and contexts. Learn Mem 9:49-57

Ni J-W, Nakato K, Morita T, Okada, M, Yamaguchi T (2001) Acetylcholinesterase inhibitors improve aged rats' memory performance in object recognition. Soc Neurosci Abstr 27:P212

Noyce JN, Kaeger C, Ryoo H, Goldsmith S (1993) Dopamine D receptors in the hippocampus and amygdala in Alzheimer's disease. Neurosci Lett 154:171-174

Otano A, Frechilla D, Cobreros A, Cruz-Orive LM, Insausti A, Insausti R, Hamon M, Rio JD (1999) Anxiogenic-like effects and reduced stereological counting of immunolabelled 5hydroxytryptamine ${ }_{6}$ receptors in rat nucleus accumbens by antisense oligonucleotides. Neuroscience 92:1001-1009

Pontecorvo MJ, Clissold DB, White MF, Ferkany JW (1991) NMethyl-aspartate antagonists and working memory performance: comparison with effects of scopolamine, propranolol, diazepam, and phenylisopropyladenosine. Behav Neurosci 105:521-535

Pouzet B, Didriksen M, Arnt J (2002) Effects of 5- $\mathrm{HT}_{6}$ receptor antagonists, SB-271046:in animal models for schizophrenia. Pharmacol Biochem Behav 71:635-643

Ramirez MJ, Cenarruzabeitia E, Lasheras B, Del Rio J (1996) Involvement of GABA systems in acetylcholine release induced by $5-\mathrm{HT}_{3}$ receptor blockade in slices from rat entorhinal cortex. Brain Res 712:274-280

Roberts JC, Reavill C, East SZ, Harrison PJ, Patel S, Routledge C, Leslie RA (2002) The distribution of $5-\mathrm{HT}_{6}$ receptors in rat brain: an autoradiographic binding study using the radiolabelled $5-\mathrm{HT}_{6}$ receptor antagonist $\left[{ }^{125} \mathrm{I}\right] \mathrm{SB}-258585$. Brain Res 934:4957

Rogers DC, Hagan JJ (2001) 5-HT 6 receptor antagonists enhance retention of a water maze task in the rat. Psychopharmacology 158:114-119

Rogers DC, Robinson TL, Quilter CA, Hunter AJ, Routledge C, Hagan JJ (1999) Cognitive enhancement effects of the selective antagonist SB-271046. Br J Pharmacol 121:22P

Rogers DC, Hatcher PD, Hagan JJ (2000) The selective 5- $\mathrm{HT}_{6}$ receptor antagonist, SB-271046-A enhances performance of maze tasks in the rat. Soc Neurosci Abstr 26:680 
Roth BL, Craigo SC, Choudhary MS, Ulver A, Monsma FJ Jr, Shen Y, Meltzer HY, Sibley DR (1994) Binding of typical and atypical antipsychotic agents to 5-hydroxytryptamine-6 and 5hydroxytryptamine-7 receptors. J Pharmacol Exp Ther 263:1403-1410

Routledge C, Bromidge SM, Moss SF, Price GW, Hirst W, Newman H, Riley G, Gager T, Stean T, Upton N, Clarke SE, Brown AM, Middlemiss DN (2000) Characterization of SB271046: a potent, selective and orally active $5-\mathrm{HT}_{6}$ receptor antagonist. Br J Pharmacol 130:1606-1612

Routledge C, Price GW, Bromidge SM, Moss SF, Newman H, Riley G, Gager T, Brown A M, Lighowler S, Middlemiss DN (1999) Characterization of SB-271046: a potent and selective 5$\mathrm{HT}_{6}$ receptor antagonist. Br J Pharmacol 121:21P

Ruat M, Traiffort E, Arrang J.M, Tardivel-Lacombe J, Diaz J, Leurs R, Schwartz JC (1993) A novel rat serotonin (5HT $)$ receptor; molecular cloning, localisation and stimulation of cAMP accumulation. Biochem Biophys Res Commun 193:268-276

Russell MGN, Baker RJ, Barden L, Beer MS, Bristow L, Broughton HB, Knowles M, McAllister G, Patel S, Castro JL (2001) $\mathrm{N}$-Arylsulfonylindole derivatives as serotonin $5-\mathrm{HT}_{6}$ receptor ligands. J Med Chem 44:3881-3895

Shirazi-Southall S, Rodriguez DE, Nomikos GG (2002) Effects of typical and atypical antipsychotics and receptor selective compounds on acetylcholine efflux in the hippocampus of the rat. Neuropsychopharmacology 26:583-594

Slassi A, Edwards L, O'Brien A, Xin T, Tehim A (2000) Preparation of 1-(arylsulfonyl)-3-(tetrahydropyridinyl)indoles as 5- $\mathrm{HT}_{6}$ receptor inhibitors. US Patent 6:133:287

Sleight AJ, Boess FG, Bos M, Levet-Trafit B, Riemer C, Bourson A (1998) Characterisation of Ro 04-6790 and Ro 63-0563: potent and selective antagonists at human and rat $5 \mathrm{HT}_{6}$ receptors. Br J Pharmacol 124:556-562

Sleight AJ, Consolo S, Martin JR, Boes M, Boess FG, Bentley JC, Bourson A (1999) 5- $\mathrm{HT}_{6}$ receptors: functional correlates and potential therapeutic indications. Behav Pharmacol 10:S86

Steckler T, Drinkenburg WHIM, Sahgal A, Aggleton JP (1998) Recognition memory in rats II. Neuroanatomical substrates. Prog Neurobiol 54:313-332

Stean TO, Hirst WD, Thomas DR, Price GW, Rogers D, Riley G, Bromidge SM, Serafinowska HT, Smith DR, Bartlett S, Deeks N, Duxon M, Upton N (2002) Pharmacological profile of SB357134: a potent, selective, brain penetrant, and orally active 5$\mathrm{HT}_{6}$ receptor antagonist. Pharmacol Biochem Behav 71:645654

Tsai S-J, Shiu H-J, Wang Y-C, Hong, C-J (1999) Association study of serotonin-6 receptor variant (C267T) with schizophrenia and aggressive disorder. Neurosci Lett 271:135-137
Tsai Y, Dukat M, Slassi A, Maclean N, Demschyshyn L, Savage JE, Roth BL, Hufesein S, Lee M, Glennon RA (2000) N1(Benzenesulfonyl)tryptamines as novel 5- $\mathrm{HT}_{6}$ antagonists. Bioorg Med Chem Lett 10:2295-2299

Umegaki H, Munoz J, Meyer RC, Spangler EL, Yoshimura J, Ikari $\mathrm{H}$, Iguchi A, Ingram DK (2001) Involvement of dopamine $\mathrm{D}_{2}$ receptors in complex maze learning and acetylcholine in ventral hippocampus of rats. Neuroscience 103:27-33

Vizi ES, Kiss JP (1998) Neurochemistry and pharmacology of the major hippocampal transmitter systems; synaptic and nonsynaptic interactions. Hippocampus 8:566-607

Vogt IR, Shimron-Abarbanell D, Neidt H, Erdmann J, Cichon S, Schulze TG, Muller DJ, Maier W, Albus M, BorrmannHassenbach M, Knapp M, Reitschel M, Propping P, Nothen MM (2000) Investigation of the human serotonin $6\left(5-\mathrm{HT}_{6}\right)$ receptor gene in bipolar affective disorder and schizophrenia. Am J Med Genet 96:217-221

Wan RQ, Pang K, Olton DS (1997) Nonhippocampal muscarinic receptors are required for nonspatial working memory. Pharmacol Biochem Behav 58:361-367

Ward RP, Dorsa DM (1996) Colocalization of serotonin receptor subtypes, 5- $\mathrm{HT}_{2 \mathrm{~A}}, 5-\mathrm{HT}_{2 \mathrm{C}}$, and $5-\mathrm{HT}_{6}$ with neuropeptides in rat striatum. J Comp Neurol 370:405-414

Wiig KA, Bilkey DK (1995) Lesions of rat perirhinal cortex exacerbate the memory deficit observed following damage to the fimbria-fornix. Behav Neurosci 109:620-630

Wilkerson A, Levin ED (1999) Ventral hippocampal dopamine $\mathrm{D}_{1}$ and $\mathrm{D}_{2}$ systems and spatial working memory in rats. Neuroscience 89:743-749

Woods ER, Phillips AG (1991) Deficits on a one trial object recognition task by rats with hippocampal CA1 lesions produced by cerebral ischemia. Neurosci Res Commun 9:177-182

Woolley ML, Marsden CA, Sleight AJ, Fone KCF (2000) Colocalisation of $5-\mathrm{HT}_{6}$ receptors on GABAergic but not cholinergic neurones in the adult rat brain. Brain Res Bull :94

Woolley ML, Marsden CA, Sleight AJ, Fone KCF (2001) A role for $5-\mathrm{HT}_{6}$ receptors in retention of spatial learning in the Morris water maze. Neuropharmacology 41:210-219

Yau JLW, Noble J, Widdowson J, Seckl JR (1997) Impact of adrenalectomy on $5 \mathrm{HT}_{6}$ and $5 \mathrm{HT}_{7}$ receptor gene expression in the rat hippocampus. Mol Brain Res 45:182-186

Yoshioka M, Matsumoto M, Togashi H, Mori K and Saito H (1998) Central distribution and function of $5 \mathrm{HT}_{6}$ receptor subtype in the rat brain. Life Sci 62:1473-1477

Yu W-YY, Tsai S-J, Lin C-H, Hsu C-P, Yang K-H, Hong C-J (1999) Serotonin-6 receptor variant (C267T) and clinical response to clozapine. Neuroreport 10:1231-1233 